\title{
RELATIONSHIP RULES WITH WORD VOCABULARY WRITING SKILLS FOR STUDENTS
}

\author{
Hendrisman \\ STKIP YayasanAbdiPendidikan \\ hendrisman63@gmail.com
}

Submit, 11-11-2019 Accepted, 21-12-2019 Publish, 24-12-2019

\begin{abstract}
This study aims to describe the relationship between vocabulary mastery and short story writing skills of Class IX students of SMPN 1, Guguak District, Lima Puluh Kota. This type of quantitative research using the method of population correlation in this study is a class IX. The research sample was taken using a cluster random sampling technique of 22 people. With the results of the study showed that the vocabulary mastery of Grade IX students was in the category of good qualifications with an average value of 80.45 on a range of $86-95 \%$ on a scale of 10. Second, short story writing skills are in more than adequate qualifications with an average value of 73 on a range of $66-75 \%$ on a scale of 10 . Third, there is a significant relationship between the two variables because $t$ arithmetic is greater than t table 2.3091 greater than 2,086. From the results of these correlations it can be concluded that there is a significant relationship between vocabulary mastery of short story writing skills
\end{abstract}

Keywords: mastery, vocabulary, writing skills, short stories

\section{INTRODUCTION}

Language is a skill that must be possessed by someone in communication. Language skills reflect a person's knowledge and experience of language rules so that interactions can be easily understood by others. There are four aspects of language skills, namely listening listening skills, speaking speaking skills, reading skills reading skills, writing skills writing skills. The four language skills have a close relationship with each other and cannot be separated, because the four language skills are basically a unified whole. The importance of writing skills is not only seen in the existence, values, functions, and processes of the activity, but also the form that results.

Language skills have an important role in various aspects of life. For example, in the education process one can express ideas, ideas, thoughts and feelings to others. The amount of mastery of vocabulary will affect one's language skills. The quality of one's language skills depends on the quantity and quality of the vocabulary they have. The richer the vocabulary we have, the more likely we 
are skilled at speaking. We need to realize and we understand that one of the aspects assessed from the grade increase of students at school is the quality of their language skills.

In accordance with the times, the formation of vocabulary also developed. Vocabulary has an important role in language teaching, because the mastery of vocabulary is very influential in language skills. Vocabulary is a factor in the formation of a language system that changes frequently. Vocabulary continues to change by taking new words from other languages, missing words, or taking other words because the situation changes. The vocabulary is very large, and no one has the whole, and also no dictionary can record all the words in any language. With mastering this vocabulary allows someone more skilled in writing.

Writing is a complex activity because the writer is required to be able to compile and organize the contents of his writing and to write in the formulation of various written languages and other writing language conventions. Behind its complexity, writing contains many benefits for a person's mental, intellectual and social development. Writing can increase intelligence, develop initiative and creativity, foster courage, and stimulate the willingness and ability to gather information. Writing is a communication activity in the form of delivering messages in writing to other parties. Writing activity involves the author as the delivery of the message or the contents of the writing, the channel or media of the writing and the reader as the recipient of the message. Writing skills are the same as other language skills, which do not come by themselves, but must go through a lot of practice and practice on a regular basis continuously.

Writing skills have been taught from basic education to college. However, it is not a measure that can guarantee a person's ability to be able to express ideas, inspiration, knowledge and experience in written form. The problem that is often raised in teaching writing is the inability of students to use good and correct Indonesian. This can be seen from the inaccurate choice of words, ineffective sentences, difficult to express ideas, difficulty choosing city vocabulary when making sentences, even unable to develop ideas regularly and systematically.

Besides that many students think that writing is a very strenuous activity. This assumption arises because writing activities do require a lot of energy, time, and earnest attention. That is why students are not skilled in writing.

There were some researchers that conducted the research in the same topic but have diffrent in some aspect, such as Rosidiana (2015) the result of this research shown that there was a improvement of students writing narrative text by using Wall Chart Media. The second resercher Meida (2017) the result of the study, there was a correlation between vocabulary mastery with the writing official letter 
The writer can get a picture of the difficulties students face in writing short stories. The problem that often arises in learning to write according to the writer's interview with Indonesian language teachers is the lack of vocabulary mastery owned by students and also the lack of students' ability to use Indonesian properly and correctly. This can be seen from the choice of words and sentences that are less effective, difficult to express ideas because of difficulty choosing words when making sentences.

\section{LITERATURE REVIEW}

The richer the vocabulary we have, the more likely we are skilled at speaking. A systematic program for vocabulary development will be influenced by age, gender, income, innate abilities, and social status. The level and depth of a person's vocabulary is the best personal index for his mental development.

According to Chaer (2010) vocabulary is the latest term that appears when we are actively searching for words or terms. Vocabulary is the oldest known term, a translation of the Dutch term woordenschat. Vocabulary is all words in a language which is the wealth of the language.

According to Chaer, (2010) vocabulary is all the words contained in syllables. Indonesian vocabulary is all the words that are in Indonesian as registered in Indonesian dictionaries. How many words there are in the Indonesian language can not be mentioned with certainty, because they are part of a language system that is very vulnerable to change and development.

Tarigan (2011) vocabulary development means placing new concepts in a better order or in additional sequences or arrangements. The main task of developing vocabulary is carried out by the teachers is to help students to see similarities and differences that they have never seen before. The development of vocabulary means more than adding new words to the vocabulary of our experience.

According to Pramesti (2015) there are four components that are responsible for language development and development planning, namely linguists, the government, language teachers, and the speaking community concerned. The four components must be interrelated and supportive. This is done so that the business can be run systematically and continuously so that optimal results are obtained. These four components are very visible in the world of education. Vocabulary mastery influences students' way of thinking and creativity in the language learning process so that vocabulary mastery can determine the quality of a student in language. Efforts to develop Indonesian vocabulary as a range of scientific communication must be linked to the structure of Indonesian grammar and emphasized on the power of careful differentiation between false statements with truth. Besides that, social rules (including professions) must be 
considered. Thus, in the development of the vocabulary there are three things that must be considered, namely the rules of grammar, rules of meaning, and social rules. Grammar rules in the development of vocabulary are intended as a basis for determining or selecting certain forms of words in accordance with the context of the sentence. The rules of meaning refer to the accuracy of the concepts represented by the paired words. Social rules in this case are used as a basis for determining the accuracy and appropriateness of choice of words with a particular environment or profession.

Tarigan (2011) the word synonym consists of sin ("same" or "similar") and onim root "name" which means "a word that is grouped with other words in the same classification based on general meaning. In other words synonyms are words that contain the same central meaning, but differ in word value. In short, synonyms are words that have the same denotation, but differ in connotation. Synonyms not only help to convey ideas in general, but also help us to make sharp and precise differences between the meanings of the word.

According to Keraf (2005) synonym is a term that can be limited as, (1) a study of various words that have the same meaning, or (2) a situation where two or more words have the same meaning. Synonyms cannot be avoided in a language, because there is an absorption process. Introduction to other languages results in the acceptance of new words that actually have an equivalent in their own language.

According to Manaf (2008) synonyms are derived from Greek, namely onoma which means 'name' and syn which means 'with'. Based on the origin of the word, synonyms mean different names but refer to the same object or concept. Generally the synonym discussed is at the lexeme or word level. Actually, synonyms are not limited to the level of words or lexemes, but synonyms are also at the level of phrases, clauses and sentences.

Example:

Dying valiantly

Beautiful-beautiful economical-saving

Strong-mighty fools

According to Tarigan (2011) an effective way to improve students' vocabulary skills is through the study of antonyms. In learning a new word, you can also learn the opposite of the word. Thus, the list of vocabulary that we have more and more. As with synonyms, this review of antonyms can help students learn words through the classification process. Studying antonyms is a part of word analysis. Using antonyms as part of word analysis clearly involves the use of alternation and continuous review, linking one concept with another, establishing associations, building and forming new knowledge based on old knowledge. 
According to Manaf (2008) antonym is the relationship of conflicting meanings or the opposite of the meaning of one word with the meanings of other words that contain differences. The words "rich" with "poor" and "far" with "close" have an opposite relationship to that meaning containing gradations. For example, the word "rich" can be contradicted by the word "poor". The word "far" can be contrasted with "near", or "very close".

Furthermore, Keraf (2005) antonym is a relation between meanings whose logical form is very different or contradictory. The term antonym is used to express the opposite of meaning. Often antonyms are considered as opposed to words from synonyms, but that assumption is very misleading. When compared with synonyms, antonyms are a natural thing in language. Although we accept the concept of antonyms in general, there are actually differences between the various types of words that are anonymous.

Example:

Strong and weak left and right

Up-close-up and down

Smart-big-small fool

Rich-poor long-short

According to Tarigan (2011) Homonyms from Yun: Homos $=$ a kind, the same; onoma = name. Homonyms are the same words, but they contain different meanings and meanings. As with the study of synonyms and antonyms, homonyms can also help students learn words through the classification process. Knowledge of homonyms clearly enriches students' vocabulary and knowledge of the practice of using dictionaries.

According to Keraf (2005) homonyms are two or more words but have the same form. Homonyms can still be distinguished further from homographs and homophones, because the similarity of shapes can be seen from the point of spelling or speech. In actual homonyms we face two or more words.

Furthermore, according to Manaf (2008) hominim can be interpreted as the same name or form, but it has a different meaning. Synonymous words have meanings depending on the context of the sentence that follows them. Therefore, we still cannot decide whether the meaning of a word that has a word without seeing it in full sentence form. If we hear the word Know there are of course two meanings that cross our brains so we have not been able to decide which is the exact meaning of the word.

Example:

Bang I: call to prayer

Bang II: short for brother

Bang III: bank

Bang IV: imitation of sound of things falling, exploding and so on. 
According to Keraf (2005) first, diction or choice of words includes the understanding of which words are used to convey an idea, how to form a grouping of the right words or use the right expressions and which style is used in a situation. Second, diction or word choice is the ability to distinguish precisely nuances of meaning from the ideas conveyed. And also the ability to find forms that suit the situation. Third, the right and appropriate choice of words is only made possible by the mastery of a large number of vocabulary or vocabulary words of that language.

According to Manaf (2008) diction is the accuracy of the choice of words or lexical units to express ideas and the compatibility of words or lexical units with the context of their use. The right word for taste is a word that can express the feelings of the speaker or writer correctly. The use of diction is usually done to make literary works more interesting, easier to understand, and also more in line with what the author of the literature wants to describe

According to Keraf (Manaf 2008) the right word is a word that can generate ideas that are right on the imagination of the listener or reader, as thought or felt by the writer or reader. Not everyone can express feelings or ideas with appropriate or good language. This is greatly influenced by the mastery of a person's vocabulary. There are so many words in Indonesian, some words have the same meaning as me, the same, me, and so forth. The words have the same meaning but the impression they have is very different. Of course the choice of words is done by taking into account the conditions in which he is talking or who is talking to whom. The choice of this word is known as diction.

According to Sukino (2010) a short story is a story that gives a dominant single impression about a character in one setting and one dramatic situation. Short stories can also be called fiction (fiction) that tells the characters and characters and has a single scope of ideas. The short story contains the author's interpretation of his concept of livelihood, both directly and indirectly. Short stories must cause readers to feel pasa, that readers feel carried away by the storyline, and short stories first attract feelings, then attract minds.

According to Aminudin (2009) short stories contain imaginary / imagination stories that are not too long. Writing short stories can help you improve creativity and science. When writing, of course you have to look for new words and styles that are unique. In addition, as writing material you are required to read source books. Furthermore, according to Sumardjo (Sukino, 2010) revealed that short stories are art, the skill of presenting stories, in which is a unified whole, unified, and there are no unnecessary parts, but there are also too many parts . Everything is fitting, integral, and contains a meaning. Short stories contain details and incidents that are deliberately chosen, and which can raise questions in the reader's mind. 
According to Sukino (2010) the short story element is divided into 6, namely as follows: Theme, the short story certainly has a message that will be conveyed to the reader. The message to be conveyed should have boundaries, have a connecting cord from the beginning to the end of the story; disposition, is a technique for displaying characters. Characterizations focus on creating the image of characters in the story; point of view, in principle is who tells the story. The perspective is like seeing an event through someone's eyes; setting, setting can be divided into 4 parts, namely: a) Setting the place, describing the location of the event that is told in a story. b) Time setting, describes when an event occurred. c) Setting the atmosphere, describing how the atmosphere in the story. d) Social setting, including matters relating to the condition of the person being told; plot, the plot can be divided into 3 namely: forward, backward, and a combination of both; Story style, the way a writer expresses or conveys his ideas to readers through language media.

According to Aminudin (2009) the short story elements are divided into 5 as follows: 1. Themes, short stories only contain one theme because of the short story. 2. Figure and character, character or character can be known by several ways that arise in the character, namely: a) through the utterances of the character, b) through the physical description of the character, c) through his thoughts. 3 . The setting (setting), one part of the short story that is considered important as the driving story. background consists of place setting, time setting, social setting. 4 . Storyline, a series of stories that are not visible. The level of conflict in the flow is: a) recognition of conflict, in this section the reader is brought to know how the seeds of conflict can arise. b) conflict arises, the emergence of conflict is due to the presence of conflict, both understandings, views, and emotions, which makes the relationship between characters tense. c) conflicts peak, in this case the conflict between the characters will make the problem be in the culmination point (peak). d) conflict subsided, conflict subsided arose after the tension of the characters in the story found their way. 5. Resolution, will appear as the final point of problems that have peaked.

According to Aminudin (2009) the characteristics of short stories consist of: 1) the story we can read only with one sitting. 2) The characters in the short story are fewer than the characters in the novel. 3) The storyline in the story is not as long as the storyline in the novel.

Furthermore, according to Lubis (Sukino, 2010) states in a short story must exist: 1) Short story contains the author's interpretation of his concept of livelihood, either directly or indirectly. 2) A short story must cause a blow, an impression in the reader's mind. 3) Short stories must cause feelings for the reader. 4) Short stories contain details and deliberately chosen incidents. 


\section{RESERCH METHOD}

This study uses the correlation method. The population in this study amounted to 153 people with sampling using the Cluster Random Sampling selected class IX.7, amounting to 22 people. The research instruments used in this study are objective tests and performance. Both tests are used to measure the level of vocabulary mastery and to measure short story writing skills. The instrument used in this research was a ring that was circulated to students who became researches. The contents contained questions about the vocabulary. As for the steps taken by the author, including: first, the author checks student's awareness. Second, the author distributes questionnaires to students. Third, students fill out a questionnaire that has been distributed by the author and filled in accordance with the answers provided. Fourth, collect back the questionnaire that has been filled out by students. Furthermore, for student learning outcomes the authors take data from the odd semester report card scores of Indonesian students

\section{FINDING}

The research process was carried out to students with two stages. The first stage of data retrieval for the first variable by providing an objective test and the second stage of data retrieval for the second variable by providing a performance test. The following explanation of the data that has been obtained.

1. Vocabulary Mastery

Based on the processing of grades, the results obtained by the vocabulary mastery of grade IX students of SMPN 1, Guguak District, Lima Puluh Kota, the highest value obtained by students is 93 and the lowest value obtained is 60 . The average value of students' vocabulary mastery is 80.45 at the qualification level. well. The level of vocabulary mastery of grade IX students of SMPN 1, Guguak District, LimaPuluh Kota in general is as follows. First, there were 1 students who got 93 marks. Second, there were 4 students who received 90 marks. Third, there were 3 students who got 87 marks. Fourth, students who scored 83 were 4 people. Fifth, students who scored 80 were 2 people. Sixth, students who scored 77 as many as 3 people. Seventh, students who get a value of 73 as many as 1 person. The eight students who scored 70 were 1 person. Ninth, students who scored 67 were 1 person. Tenth, students who score 63 as many as 1 person. Eleventh, students who score 60 as many as 1 person.

2. Short Story Writing Skills

The following will describe the results of short story writing skills of class IX students of SMP Negeri 1 Guguak District, Lima Puluh Kota Regency. Based on the data obtained by the students' short story writing skills are as follows. The highest score obtained by students is 87.5 and the lowest score obtained is 50 . The average value of students' short story writing skills is 73.57 , 
which is more than adequate qualification. The description of mastery level of short story writing skills of class IX students of SMPN 1, Guguak District, LimaPuluh Kota Regency in general is as follows. First, students who score 87.5 total people. Second, students who scored 75 totaled 12 people. Third, students who score 62.5 amount to 5 people. Fourth, students who score 50 are 1 people.

3. The Relationship of Vocabulary Mastery with Short Story Writing Skills

The relationship between mastery of vocabulary with short story writing skills of class IX students of SMP Negeri 1 Guguak District, Lima Puluh Kota is known by the Product Moment correlation formula. Vocabulary mastery value data as variable $\mathrm{X}$ and short story writing skill data as variable $\mathrm{Y}$. Data value of each variable is entered in the following table.

Table 1. Correlation of Vocabulary Mastery with Short Story Writing Skills

\begin{tabular}{ccccccc}
\hline No & $\begin{array}{c}\text { Sample } \\
\text { Code }\end{array}$ & $\mathbf{X}$ & $\mathbf{Y}$ & $\mathbf{X}^{\mathbf{2}}$ & $\mathbf{Y}^{2}$ & $\mathbf{X Y}$ \\
\hline 1 & 01 & 87 & 75 & 7569 & 5625 & 6525 \\
\hline 2 & 02 & 90 & 75 & 8100 & 5625 & 6750 \\
\hline 3 & 03 & 87 & 75 & 7569 & 5625 & 6525 \\
\hline 4 & 04 & 87 & 62,5 & 7569 & 3906,25 & 5437,5 \\
\hline 5 & 05 & 77 & 75 & 5929 & 5625 & 5775 \\
\hline 6 & 06 & 63 & 68,75 & 3969 & 4726,56 & 4331,25 \\
\hline 7 & 07 & 83 & 75 & 6889 & 5625 & 6225 \\
\hline 8 & 08 & 83 & 75 & 6889 & 5625 & 6225 \\
\hline 9 & 09 & 70 & 62,5 & 4900 & 3906,25 & 4375 \\
\hline 10 & 10 & 67 & 75 & 4489 & 5625 & 5025 \\
\hline 11 & 11 & 77 & 75 & 5929 & 5625 & 5775 \\
\hline 12 & 12 & 90 & 87,5 & 8100 & 7656,25 & 7875 \\
\hline 13 & 13 & 77 & 81,25 & 5929 & 6601,56 & 6256,25 \\
\hline 14 & 14 & 77 & 87,5 & 5929 & 7656,25 & 6737,5 \\
\hline 15 & 15 & 80 & 62,5 & 6400 & 3906,25 & 5000 \\
\hline 16 & 16 & 93 & 75 & 8649 & 5625 & 6975 \\
\hline 17 & 17 & 90 & 81,25 & 8100 & 6601,56 & 7312,5 \\
\hline 18 & 18 & 83 & 87,5 & 6889 & 7656,25 & 7262,5 \\
\hline 19 & 19 & 83 & 62,5 & 6889 & 3906,25 & 5187,5 \\
\hline 20 & 20 & 70 & 50 & 4900 & 2500 & 3500 \\
\hline 21 & 21 & 90 & 75 & 8100 & 5625 & 6750 \\
\hline 22 & 22 & 80 & 75 & 6400 & 5625 & 6000 \\
\hline & $\mathrm{N}=22$ & $\mathrm{X}=1784$ & $\mathrm{Y}=1618$, & $\mathrm{X}^{2}=14608$ & $\mathrm{Y} 2=120156,3$ & $\mathrm{XY}=131512,5$ \\
\hline & & & & 6 & & \\
\hline
\end{tabular}

Rxy $=\frac{n \sum \sum X Y-\sum X \sum Y Y}{\sqrt{\left[n \sum \sum X^{2}-\left(\sum X\right)^{2}\right]\left[n \sum \sum Y^{2}-\left(\sum Y\right)^{2}\right]}}$ 


$$
\begin{aligned}
& =\frac{22,131512,5-(1784)(1618,75)}{\sqrt{\left[22,146086-(1784)^{2}\right]\left[22,120156,3-(1618,75)^{2}\right]}} \\
& =\frac{2893275-2876700}{\sqrt{[3213892-3182656][2643438,6-2600156,25]}} \\
& =\frac{16575}{\sqrt{[31236][43282,35]}} \\
& =\frac{16575}{\sqrt{1351967484,6}} \\
& =\frac{16575}{36769,11} \\
& =0,4508 \\
& =0,45
\end{aligned}
$$

Hypothesis testing

$$
\begin{aligned}
\mathrm{T} & =\sqrt{\frac{r^{2}(n-1)}{1-r^{2}}} \\
& =\sqrt{\frac{0,45^{2}(22-1)}{1-0,45^{2}}} \\
& =\sqrt{\frac{0,2025(21)}{1-0,2025}} \\
& =\sqrt{\frac{4,2525}{0,7975}} \\
& =\sqrt{5,3322} \\
& =2,3091
\end{aligned}
$$

After the calculated t value is obtained, the next step is to compare the calculated $t$ value with $t$ table at a significant level of 0.05 with the degree of freedom n-2. For more details, see the following table.

Table 2. Hypothesis Testing

\begin{tabular}{l|l|l|l}
\hline $\mathbf{R}$ & T count & $\mathbf{n - 2}(22-2)$ & Ttable \\
\hline
\end{tabular}




\begin{tabular}{l|c|c|c}
\hline & & & $\mathbf{0 , 0 5}$ \\
\hline 0,4508 & 2,3091 & 20 & 2,086 \\
\hline
\end{tabular}

From the results of testing the above hypothesis it can be concluded that there is a significant relationship between vocabulary mastery and short story writing skills significant 0.05 with degrees of freedom $n-2$, meaning $H_{-} 0$ in this study was rejected and $\mathrm{H} \_1$ is accepted because the test results in this study prove that $t$ arithmetic is greater than $t$ table that is $2.3091>2.086$. It can be concluded that there is a significant relationship between vocabulary mastery and short story writing skills

\section{DISCUSSION}

In this section three things will be discussed, namely: (1) vocabulary mastery of class (2) short story writing skills (3) the relationship of vocabulary mastery words with short story writing skills. Based on the data description and data analysis, it is known that the vocabulary mastery is good category with an average value of 80.45 on a range of $76-85 \%$ on a scale of 10 . Viewed from the results of analyzing data and research conducted, it can be concluded that the short story writing skills are in more than adequate qualifications with an average rating of 73 on a range of $66-75 \%$ on a scale of 10 . Chaer (2010) vocabulary is the latest term that appears when we are actively searching for words or terms. Vocabulary is the oldest known term, a translation of the Dutch term woordenschat. Vocabulary is all words in a language which is the wealth of the language.Based on the results of the correlations between the two variables, the $r$ count is 0.4508 and the $t$ value is 2.3091 . Therefore, it can be concluded that the mastery of vocabulary with short story writing skills, there is a significant relationship at the 0.05 level with degrees of freedom n-2 $(22-2=20)$. Based on this, H_O in this study was rejected while H_1 was accepted because the results of testing the hypothesis in the study proved that $\mathrm{t}$ count was greater than $\mathrm{t}$ table, that is 2.3091 greater than 2.086 .

\section{CONCLUSION}

There is a significant relationship between vocabulary mastery and short story writing skills of class IX students of SMPN 1, Guguak Subdistrict, Lima Puluh Kota

\section{REFERENCES}

Aminuddin. (2009). Kreatif Membuat Ragam Tulisan. Bandung: Puri Pustaka. Chaer, A. (2010). Telaah Bibliografi Kebahasaan Bahasa Indonesia. Melayu. Jakarta: Rineka Cipta. 
Keraf, G. (2005). Diksidan Gaya Bahasa. Jakarta: Gramedia Pustaka Utama.

Maida, H. (2017). Hubungan antara Penguassan Kosa Kata dengan Penulisan Surat Resmi Siswa SMPN 3 Payakumbuh.(Skripsi). Payakumbuh: STKIP Yayasan Abdi Pendidikan.

Manaf, N., A. (2008). Semantik Teori Dan Terapannya Dalam Bahasa Indonesia. Padang: Sukabina offset.

Pramesti, D., U. (2015). Peningkatan Penguasaan Kosakata Bahasa Indonesia Dalam Keterampilan Membaca Melalui Teka-Teki Silang. 17-40

Rosidiana. (2015). Peningkatan Keterampilan Menulis Karangan Narasi menggunakan Media Wall Chart Siswa Kelas II SDN Pancur 2 Saleman (Skripsi). Yokyakarta: UNY

Sukino. (2010). Menulis Itu Mudah. Yogyakarta: Pustaka Populer LKiS.

Tarigan, H. G. (2011). Menulis Sebagai Suatu Keterampilan Berbahasa. Bandung: Angkasa. 